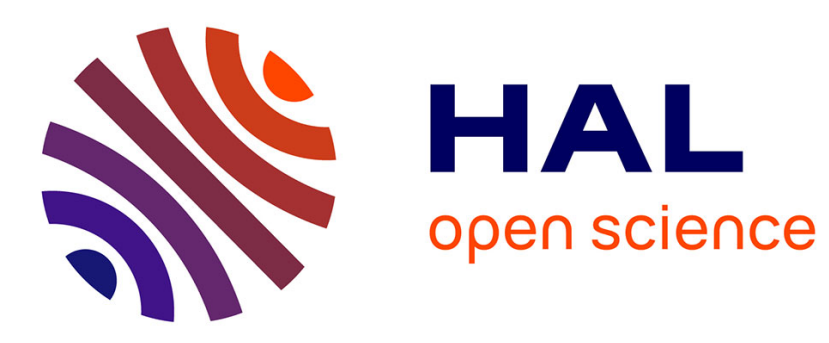

\title{
A data-driven modeling method to analyze cardiomyocyte impedance data
}

Levy Batista, Thierry Bastogne, Franck Atienzar, Annie Delaunois, Jean-Pierre Valentin

\section{- To cite this version:}

Levy Batista, Thierry Bastogne, Franck Atienzar, Annie Delaunois, Jean-Pierre Valentin. A datadriven modeling method to analyze cardiomyocyte impedance data. Safety Pharmacology Society 2017 Annual Meeting, SPS 2017, Sep 2017, Berlin, Germany. hal-01670012

\section{HAL Id: hal-01670012 \\ https://hal.science/hal-01670012}

Submitted on 21 Dec 2017

HAL is a multi-disciplinary open access archive for the deposit and dissemination of scientific research documents, whether they are published or not. The documents may come from teaching and research institutions in France or abroad, or from public or private research centers.
L'archive ouverte pluridisciplinaire HAL, est destinée au dépôt et à la diffusion de documents scientifiques de niveau recherche, publiés ou non, émanant des établissements d'enseignement et de recherche français ou étrangers, des laboratoires publics ou privés. 


\section{A data-driven modeling method to analyze cardiomyocyte impedance data \\ L. BATISTA ${ }^{1,2,3}$, T. BASTOGNE ${ }^{1,2,3}$, F. ATIENZAR ${ }^{4}$, A. DELAUNOIS ${ }^{4}$, J.-P. VALENTIN ${ }^{4}$ \\ CRAN, 2 INRIA BIGS, ${ }^{3}$ CYBERnano, ${ }^{4}$ UCB}

Background. One goal of the Comprehensive in vitro ProArrhythmia Assay initiative is to predict more accurately potentially torsadogenic compounds in an earlier stage of drug development. To that aim one of the CiPA component is to assess capabilities of label-free in vitro assays (impedance and extracellular field potential signals) applied to human stem cell-derived cardiomyocytes.

\section{Objectives}

Each cardiomyocyte impedance assay may contain more than 25000 signals recorded with a sampling rate of $77.5 \mathrm{~Hz}$ during periods of 20s. Therefore, the objective is to automate the processing and analysis of those data to assess contractility effects in early steps of drug development.

\section{Methods}

The proposed solution relies on three main steps. The first one consists in calculating five indicators (FASTI) characterizing the time variations of frequency, amplitude, shape, trends and irregularity of beatings. In a second phase, two summary statistics are proposed to test the concentration effect of compounds on the five FASTI indicators. Finally, results of the previous statistical tests are aggregated in a cardio-effect grade to compare the tested molecules in a cardio-impact scale graduated from 0 (no influence) to 10 (highly disturbed beating). This innovative approach was tested using in vitro data obtained from cell impedance analysis of three known molecules (2 cardiotoxic and 1 non-cardiotoxic compounds).

\section{Results}

These preliminary results have corroborated the ability of the proposed method to efficiently discriminate the effects of the tested drugs. The main advantage of this approach is that it provides rapid and reliable analysis of complex signals. Median concentrations of the contractility effects have been estimated for the three tested molecules are consistent with the recent publications.

\section{Conclusion}

The proposed solution speeds up the analysis of cardiomyocyte impedance data and allows biologists to quickly know when alterations of the cardiomyocyte contractility occur, which characteristics is disturbed and the concentration responses of tested compounds. In perspective, to confirm the obtained results, the next step will evaluate this new method to a larger batch of molecules. To improve the risk classification efficiency, one main perspective consists in testing the added value brought by coupling the analysis of impedance and field potential signals.


Fig. 1Real-time measurement of cardiomyocyte impedance responses (left) and Overview of the method used to analyze the Cl data (right)
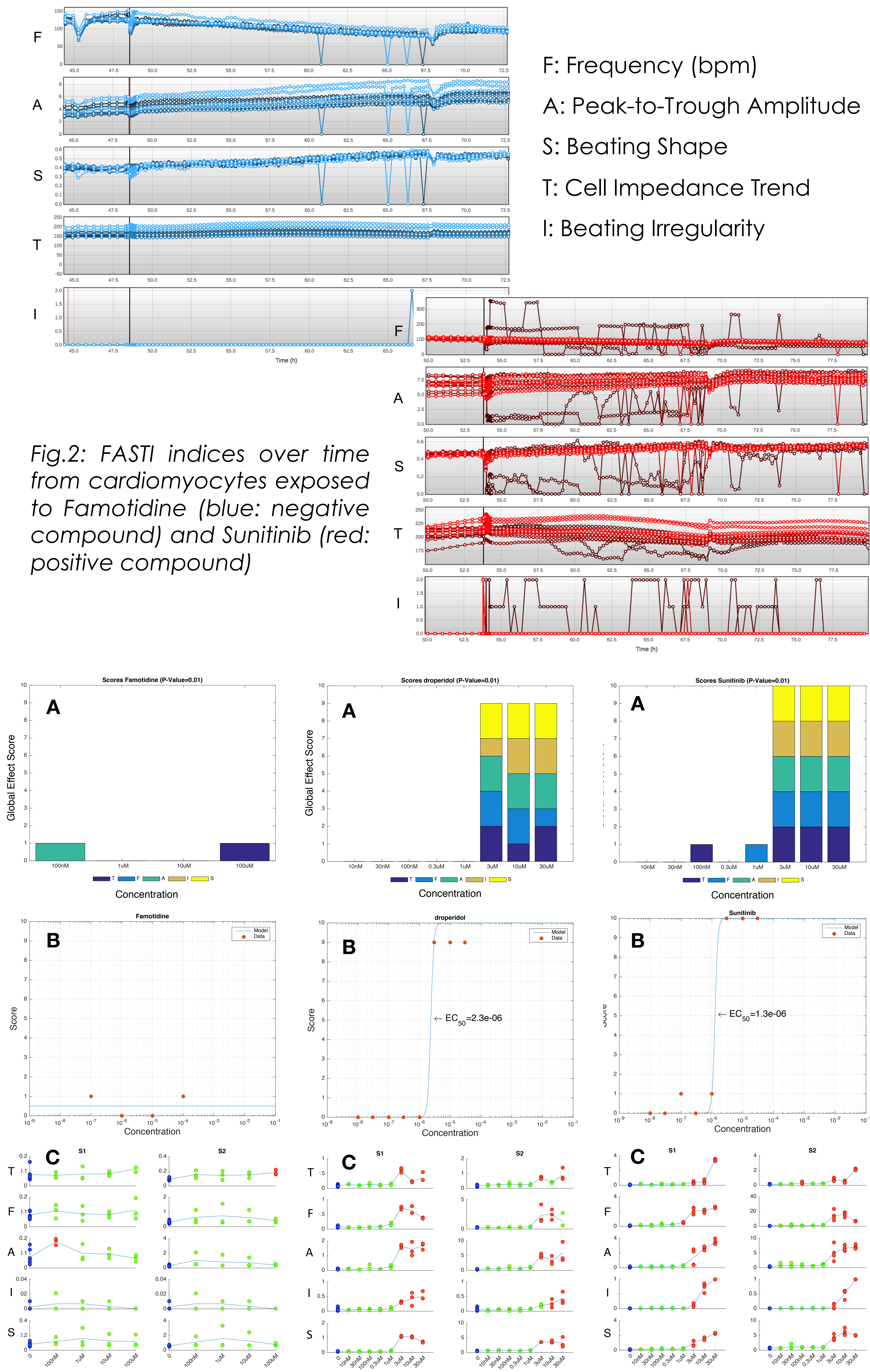

Fig.3: Summary of concentration-effects induced by Famotidine (left), Droperidol (middle) and Sunitinib (right) on mouse cardiomyocytes. A. Global effect scores. Minimum score (0) means that the FASTI parameters are not significantly different compared to control data (cardiomyocytes exposed to $0.1 \%$ DMSO). A score of 10 corresponds to severe effects often manifested by a beating arrest of the cardiomyocytes. B. Estimated EC50 value: N.S. for Famotidine and $1.3 \mu \mathrm{M}$ for Sunitinib. C. FASTI indices: blue dots correspond to control values, green dots indicate no significant change w.r.t. control and red dots point out significant changes compared to control data. 